\title{
ADDITIONAL ARTICLES ABSTRACTED IN ACP JOURNAL CLUB
}

The following articles are abstracted in the September/October 2002 issue of ACP Journal Club. The declarative title of each abstract as published in ACP Journal Club precedes the article citation.

\section{Therapeutics}

Isotonic hydration reduced contrast media associated nephropathy in elective or emergency coronary angioplasty

Mueller C, Buerkle G, Buettner HJ, et al. Prevention of contrast media-associated nephropathy: randomized comparison of 2 hydration regimens in 1620 patients undergoing coronary angioplasty. Arch Intern Med 2002 Feb 11;162:329-36.

Planned angiography after percutaneous coronary intervention increased reinterventions but did not affect mortality or MI ten Berg JM, Kelder JC, Suttorp MJ, et al. Influence of planned six-month follow-up angiography on late outcome after percutaneous coronary intervention. A randomized study. J Am Coll Cardiol 2001 Oct;38:1061-9.

Primary percutaneous coronary intervention was more effective than thrombolytic therapy for acute MI

Aversano T, Aversano LT, Passamani E, et al., for the Atlantic Cardiovascular Patient Outcomes Research Team (C-PORT). Thrombolytic therapy vs primary percutaneous coronary intervention for myocardial infarction in patients presenting to hospitals without on-site cardiac surgery: a randomized controlled trial.JAMA 2002 Apr 17;287:1943-51.

Mild hypothermia improved neurologic outcome and reduced mortality after cardiac arrest because of ventricular arrhythmia The Hypothermia After Cardiac Arrest Study Group. Mild therapeutic hypothermia to improve the neurologic outcome after cardiac arrest. N Engl J Med 2002 Feb 21;346:549-56.

Review: Noninvasive ventilation reduces mortality in acute respiratory failure

Peter JV, Moran JL, Phillips-Hughes J, et al. Noninvasive ventilation in acute respiratory failure: a meta-analysis update. Crit Care Med 2002 Mar;30:555-62.

Review: Albumin increases mortality in critically ill patients Alderson P, Bunn F, Lefebvre C, et al. Human albumin solution for resuscitation and volume expansion in critically ill patients. Cochrane Database Syst Rev 2002;(1):CD001208 (latest version 26 Nov 2001).

Review: Intensive insulin pump therapy slightly improves glycemic control in type 1 diabetes

Pickup J, Mattock M, Kerry S. Glycaemic control with continuous subcutaneous insulin infusion compared with intensive insulin injections in patients with type 1 diabetes: meta-analysis of randomised controlled trials. BMJ 2002 Mar 23;324:705-8.

Review: Interferon $a-2 b$ is effective for biochemical and virologic outcomes in acute hepatitis $\mathrm{C}$ virus infection

Poynard T, Regimbeau C, Myers RP, et al. Interferon for acute hepatitis C. Cochrane Database Syst Rev 2002;(1):CD000369 (latest version 19 Jul 2001).

Review: Pygeum africanum extracts improve symptoms and urodynamics in symptomatic benign prostatic hyperplasia

Wilt T, Ishani A, Mac Donald R, et al. Pygeum africanum for benign prostatic hyperplasia. Cochrane Database Syst Rev 2002;(1):CD001044 (latest version in 16 Nov 2001).

Review: Selegiline improves symptoms and levodopa is better than pramipexole for motor function in untreated Parkinson disease

Miyasaki JM, Martin W, Suchowersky O, et al. Practice parameter: initiation of treatment for Parkinson's disease: an evidence-based review. Report of the Quality Standards Subcommittee of the American Academy of Neurology. Neurology 2002 Jan 8;58:11-7.

Review: Proton pump inhibitors alleviate symptoms of functional (nonulcer) dyspepsia but may not be better than $\mathrm{H}_{2}$-antagonists

Shiau JY, Shukla VK, Dubé C. The efficacy of proton pump inhibitors in adults with functional dyspepsia. Technology Report No. 22. Ottawa: Canadian Coordinating Office for Health Technology Assessment (CCOHTA); 2002. www.ccohta.ca.

\section{Prognosis}

Patients who survived the first 30 days after a first episode of status epilepticus had increased mortality at 10 years

Logroscino G, Hesdorffer DC, Cascino GD, et al. Long-term mortality after a first episode of status epilepticus. Neurology 2002 Feb 26;58:537-41.

\section{Quality Improvement}

Review: In hospital care pathways for acute stroke do not improve clinical outcomes but do lower quality of life

Kwan J, Sandercock P. In-hospital care pathways for stroke. Cochrane Database Syst Rev 2002;(2):CD002924 (latest version 4 Feb 2002). 